\title{
A Sensitivity Study on the Soil Parameter-Boundary Layer Height Interrelationship
}

\author{
Hajnalka Breuer, ${ }^{1}$ Ferenc Ács, ${ }^{1}$ Ákos Horváth, ${ }^{2}$ Borbála Laza, ${ }^{1}$ István Matyasovszky, \\ Péter Németh, ${ }^{3}$ Tamás Weidinger, ${ }^{1}$ and Kálman Rajkai ${ }^{4}$
}

${ }^{1}$ Department of Meteorology, Eötvös Loránd University, Pázmány P. setany 1/A, 1117 Budapest, Hungary
${ }^{2}$ Hungarian Meteorological Service, Vitorlás utca 17, 8600 Siófok, Hungary
${ }^{3}$ Marcell György Observatory, Hungarian Meteorological Service, P.O. Box 39, 1675 Budapest, Hungary
${ }^{4}$ Research Institute for Soil Science and Agricultural Chemistry of the Hungarian Academy of Sciences, Herman Ottó u. 15.,
1022 Budapest, Hungary

Correspondence should be addressed to Hajnalka Breuer, bhajni@nimbus.elte.hu

Received 5 March 2012; Accepted 2 April 2012

Academic Editors: L. E. Venegas, D.-Y. Wang, and C. Zerefos

Copyright ( $\odot 2012$ Hajnalka Breuer et al. This is an open access article distributed under the Creative Commons Attribution License, which permits unrestricted use, distribution, and reproduction in any medium, provided the original work is properly cited.

\begin{abstract}
Simulations with the WRF model have been carried out with high resolution soil data to analyze its effect on planetary boundary layer (PBL) development. The default soil texture distribution of $5^{\prime}$ horizontal resolution has been replaced with a $30^{\prime \prime}$ one on the basis of the Digital Kreybig Soil Information System and Hungarian Agrogeological Database in Hungary. Soil parameter values determined from HUNSODA and MARTHA Hungarian soil databases were also compared. Comparison of PBL height simulations and measurements obtained by radiometer and windprofiler shows that the impact of soil parameter differences on PBL height evolution is not negligible. The latent heat flux and PBL height daytime courses show significant $(P<0.01)$ differences over more than $50 \%$ of the model domain covering the Carpathian basin.
\end{abstract}

\section{Introduction}

The land-surface is the key climate system component in modeling of the lower atmosphere not only in the global circulation but also in the mesoscale modeling systems [1]. Since surface properties are highly variable in both space and time, the quantification of land-surface-atmosphere interaction processes is still a major challenge. The surfaceatmosphere coupling is ensured by the surface energy budget equation. So, surface inhomogeneities can induce fluctuations in the spatially averaged surface energy budget terms, these in return affect the lower atmosphere [2], even up to the top of the planetary boundary layer (PBL) [3]. One major factor in the energy budget is the available soil moisture, affecting both bare soil evaporation and transpiration. However, soil moisture depends on many factors, such as soil texture, spatial variability of soil properties, and soil hydrophysical parameters. Soil parameters inherently differ between independent and local soil datasets, where the local dataset proves to be more accurate on a region's characterization (e.g., $[4,5])$ ). It is also known that parameter variability in soil textures can be greater than the differences in soil textures [6]. Though for soil hydraulic modeling this information is important, it arises the question whether the resulting difference in latent heat flux has substantial effect on PBL height. There had been many investigations on the role of soil in weather events (e.g., [7, 8]), but more investigation is needed (e.g., $[9,10]$ ) as the mesoscale weather prediction systems develop.

In this study the popular WRF model is used to analyze the effects of soil database differences on PBL height changes. The simulations are organized as follows: a $25600 \mathrm{~km}^{2}$ model domain with $1 \mathrm{~km}$ resolution was nested into a $450000 \mathrm{~km}^{2}$ large model domain with $3 \mathrm{~km}$ resolution. This territory is situated approximately in center of the Carpathian-basin. In order to be able to analyze the effect of soil parameters on PBL changes, a soil texture distribution of very high 
resolution $\left(30^{\prime \prime}\right)$ has also been added. The hydrophysical parameters of soil textures are defined with the use of two Hungarian soil databases. Both contain soil samples from Hungary, but there is one order of magnitude difference in their sizes. This remarkable difference results in parameter value differences. Simulated PBL height changes are compared to radiometric and windprofiler determined PBL heights. Moreover, significance test on the simulated daytime course of latent heat flux and PBL height is also done to asses the effect of soil parameters.

\section{Methods}

2.1. Estimation of PBL Height. The height of PBL can be determined from various methods $[11,12]$. The uncertainty range of PBL heights obtained by different instruments is 100-700 m. From many methodological options available for windprofiler, we tested separately the maximum signalto-noise ratio (SNR) [13], the maximum windshear height, and the wind speed and wind direction change method. In most cases the SNR proved to be acceptable, clearly showing diurnal evolution of PBL; therefore, we choose to compare simulations to this method. Evaluating radiometric measurement data, we used the following PBL height determination criteria: the level of disappearing inversion during nighttime and the level of $0.4 \mathrm{~K} / 100 \mathrm{~m}$ gradient in potential equivalent temperature during daytime [14].

2.2. Significance Test. Diurnal change of PBL height and latent heat flux is an autoregressive stochastic periodic process in a statistical sense and depends mainly on incoming radiation. In order to separate the effect of soil parameters in the diurnal courses, the natural diurnal course has been alienated from the simulated quantities with Fourier-series analysis. A more detailed description can be found in [15]. The significances were tested to $P<0.01$ probability.

\section{Soil Texture}

The analysis required as precise spatial distribution of soil texture as possible. The soil texture types are defined as the FAO 12 types. In the surrounding countries the available FAO-STATSGO distribution was used, which has a $5^{\prime}$ resolution $(\approx 10 \mathrm{~km})$. In Hungary a more detailed Digital Kreybig Soil Information System (DKSIS) [16] was applied. The database consists of soil information on a $1: 25000$ scale. Overall in Hungary, a field campaign was enacted from 1935 to 1951 to create a comprehensive and detailed soil information database. Digital processing of these maps begun in 1998, and it ended only recently. The creation of the database included a compilation of the maps [17] and soil information, and updating them with recent remotely sensed images and spatial database. The DKSIS was also compiled together with the Hungarian Agrogeological Database (HAD) which consists information of soil particle size distribution in soil samples [18]. From the available particle size distribution, the FAO classification was determined and interpolated [19] to the $30^{\prime \prime}$ soil texture grid used by the WRF model. As it can be seen in Figure 1, the distribution of soil

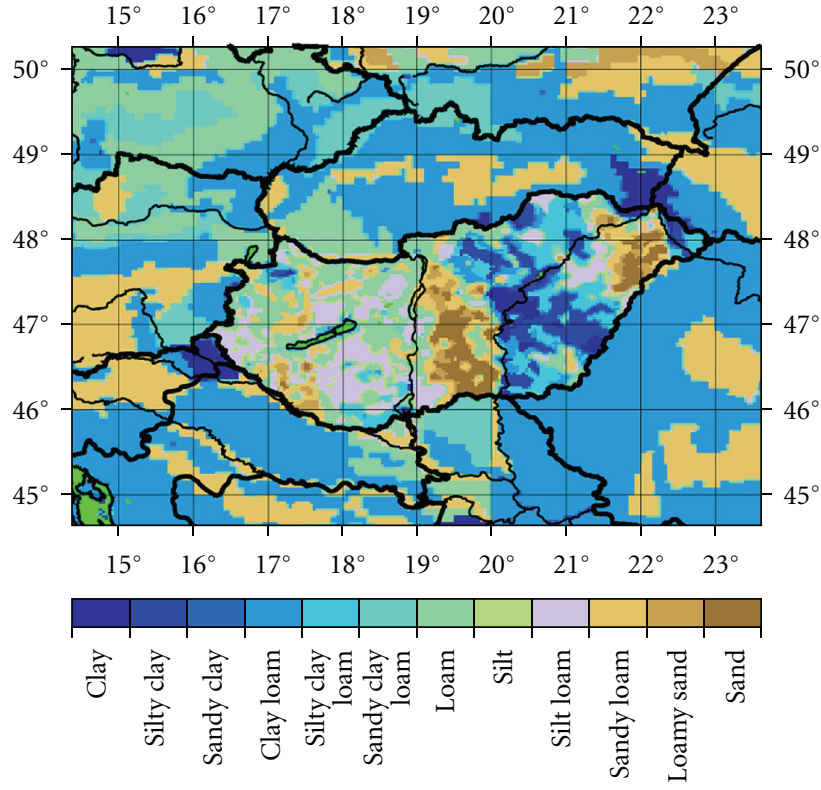

Figure 1: Soil texture distribution in the model area.

textures is much more detailed in Hungary. Originally there were only 6 types of soil textures over the simulation area, but with the new soil information all 12 types can be found.

\section{Soil Parameters}

In this study, two Hungarian soil databases and the parameters derived from them are compared. The first one is the HUNSODA [20, 21]. It contains information on 476 soil samples. Each sample refers to one soil horizon. The samples were taken only from plains. Measured soil moisture is available for soil moisture retention curves in the whole suction range ( $\mathrm{pF} 0,0.4,1,1.5,2,2.3,2.7,3.4,4.2$, and 6.1). The other soil database is the MARTHA [22]. The number of soil samples is about 15 times larger $(\approx 7500$ soil samples $)$ than in the former case. The spatial extent of the collected information is about 5 times larger $(\approx 2300$ sample sites $)$ with respect to the former database. The samples originate from the whole country. Information on soil moisture retention curves is available at least for standard $\mathrm{pF}$ values: $0,2.5,4.2$, and 6.2 for every sample. Soil parameters were determined using Campbell's [23] method, where the field capacity is defined at the $\mathrm{pF}=2.5$ value. The greatest differences in soil hydraulic parameters were found for sand, loamy sand, clay loam, and silty clay (Table 1). For loamy sand the field capacity differs with almost $200 \mathrm{~mm} / \mathrm{m}$, and the saturated soil moisture with $170 \mathrm{~mm} / \mathrm{m}$. The least differences were found for silt loam, sandy clay loam, and loam.

\section{Measurements}

For this study, vertical profiling measurements were conducted at the observatory of Szeged (46.25572N, 20.09023E) by the Hungarian Meteorological Service. The site is outside 


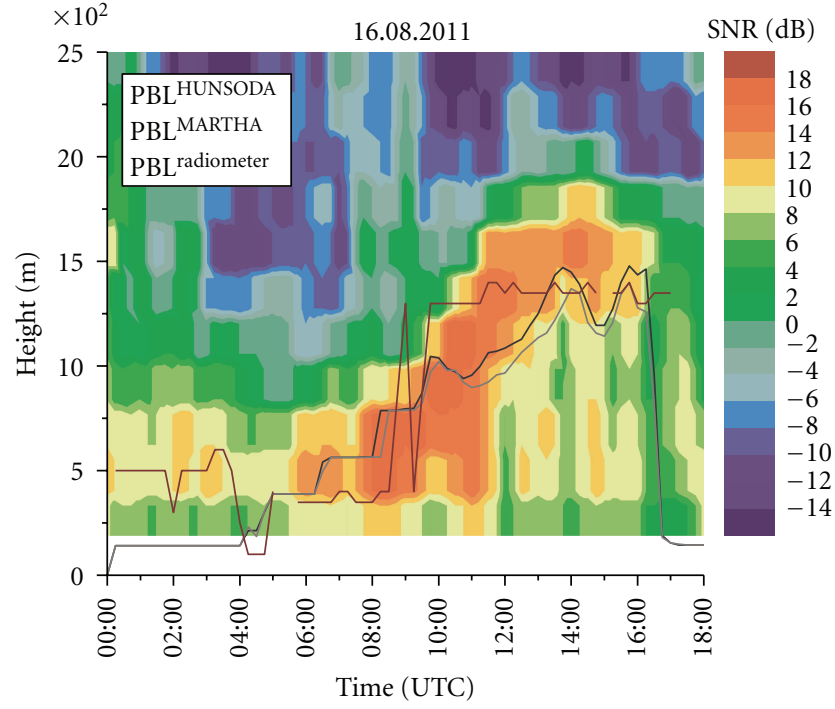

(a)

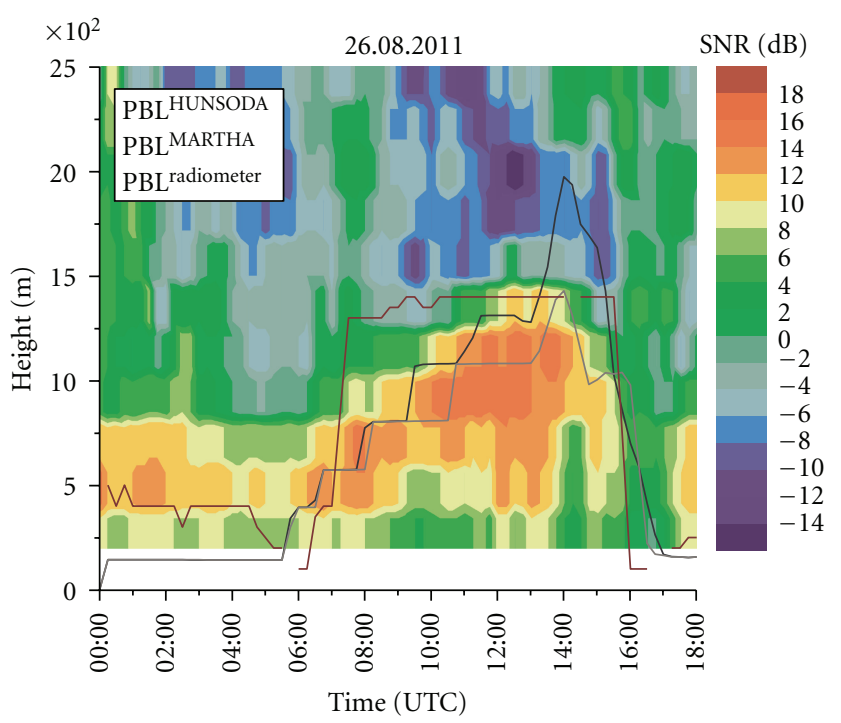

(b)

FIGURE 2: Windprofiler SNR compared to PBL heights estimated from radiometer temperature profile and simulated using HUNSODA and MARTHA soil parameters (a) August 16, 2011, (b) August 26, 2011.

TABLE 1: HUNSODA-MARTHA soil parameter value differences ( $b$-pore size index, $\Theta_{s}$-saturated soil water content, $\Theta_{f}$ - field capacity, $\Theta_{w}$-wilting point) (minimum and maximum MARTHA parameter values are in brackets).

\begin{tabular}{lcccc}
\hline Soil texture & $b$ & $\begin{array}{c}\Theta_{w} \\
{[\mathrm{~mm} / \mathrm{m}]}\end{array}$ & $\begin{array}{c}\Theta_{f} \\
{[\mathrm{~mm} / \mathrm{m}]}\end{array}$ & $\begin{array}{c}\Theta_{s} \\
{[\mathrm{~mm} / \mathrm{m}]}\end{array}$ \\
\hline Sand & -0.34 & -5 & -73 & 85 \\
Loamy sand & -0.87 & -48 & -194 & 172 \\
Sandy loam & -0.57 & -12 & -42 & 37 \\
Silt loam & -0.49 & -2 & -3 & 5 \\
Silt & 0.64 & 15 & -54 & 29 \\
Loam & -0.43 & -13 & -29 & -1 \\
Sandy clay & -0.27 & 18 & 6 & -6 \\
loam & & & & \\
Silty clay & -0.67 & -17 & -31 & 21 \\
loam & -0.42 & -41 & -86 & 114 \\
Clay loam & 0.17 & 34 & 17 & 85 \\
Sandy clay & 1.13 & 10 & 78 & -34 \\
Silty clay & -0.88 & -13 & -48 & 48 \\
Clay & & & & \\
\hline
\end{tabular}

the city surrounded by agricultural cultivations (corn, barley). During the measurement period (August 1-31, 2011), the sum of precipitation was only $1.9 \mathrm{~mm}$; this is about $1 / 30$ of monthly average. Two instruments were used to verify the simulations, a radiometer and a windprofiler. The Radiometrics MP-3000A is a ground-based microwave radiometer which can continuously measure temperature, humidity, liquid water profiles to $10 \mathrm{~km}$ height. The instrument has 21 calibrated channels in $22-30 \mathrm{GHz}$ (K-band) and 14 in $51-$ $59 \mathrm{GHz}$ (V-band); it is also equipped with sensors for surface temperature, relative humidity, and pressure. Measurements are available from $0-500 \mathrm{~m}$ height at every 50 meters, from 500-2000 m height at every 100 meters, and from 2000$10000 \mathrm{~m}$ at every 250 meters. At the site a Vaisala LAP3000 is also used which is a lower atmospheric wind profiler with radio acoustic sounding system (RASS). Measurements of vertical profiles of horizontal wind speed and direction are available up to an altitude of $4 \mathrm{~km}$. The instrument's operating frequency is $1290 \mathrm{MHz}$; measurements are available at every 15 minutes. The vertical resolution of the measurements is $220 \mathrm{~m}$ starting at around $150 \mathrm{~m}$.

\section{Model Setup}

Simulations were carried out with the WRF-ARW v3.1 model [24]. The number of vertical levels was 44 , the mother domain's horizontal resolution was set to $3 \mathrm{~km}$, while the nest's was $1 \mathrm{~km}$. The respective domain size was $235 \times$ 211 grid points covering the Carpathian-basin and $160 \times$ 160 grid points centered by a synoptic station around the south border of Hungary, on the bank of the Tisza River. Simulation step size was set to 15 and 5 seconds, and the 6th order diffusion integration option was chosen. From 00 UTC the model run was 18 hour long and no measurements were assimilated. Both domains were run with the same physical parameterizations: RRTM [25] for radiation, BougeaultLacarrere [26] for PBL, Thompson [27] for microphysics and Noah [28] for land-surface processes. From the point of view of the analysis it has to be noted that the PBL scheme predicts the turbulent kinetic energy (TKE) to estimate the PBL height. Also in the Noah scheme the latent heat flux mainly depends on the difference of soil moisture and wilting point, and the difference in field capacity and wilting point. Initial and boundary conditions were taken from ECMWF MARS (European Centre for Medium-Range Weather Forecasts 

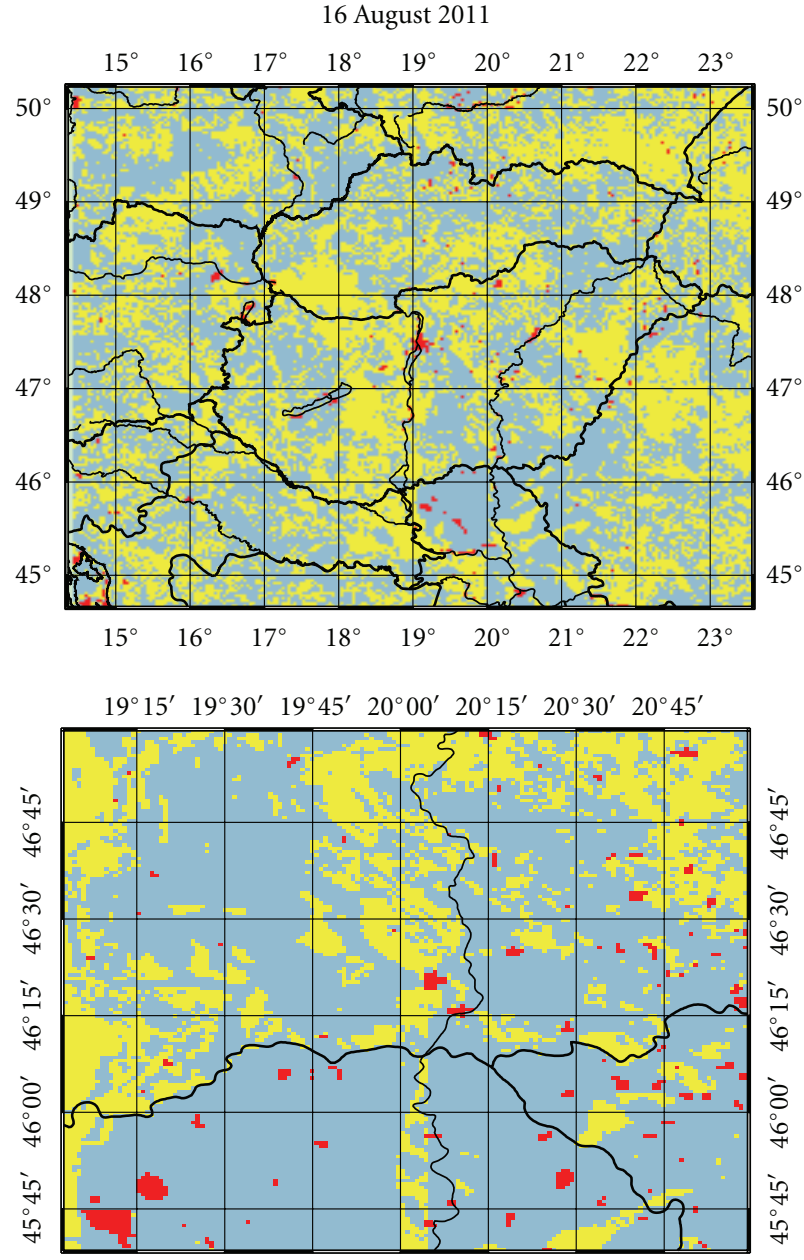

$19^{\circ} 15^{\prime} \quad 19^{\circ} 30^{\prime} \quad 19^{\circ} 45^{\prime} \quad 20^{\circ} 00^{\prime} \quad 20^{\circ} 15^{\prime} \quad 20^{\circ} 30^{\prime} \quad 20^{\circ} 45^{\prime}$

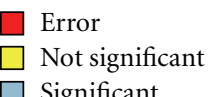

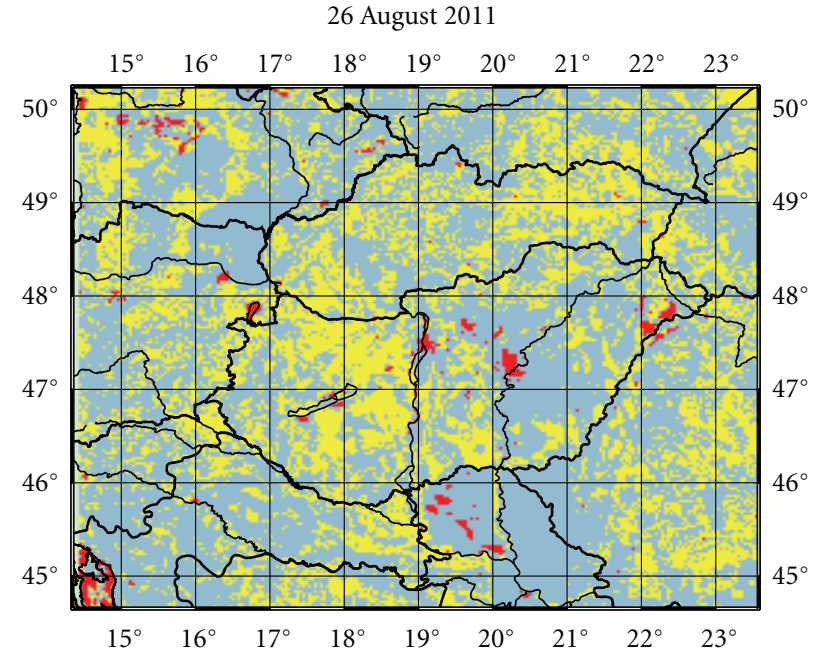

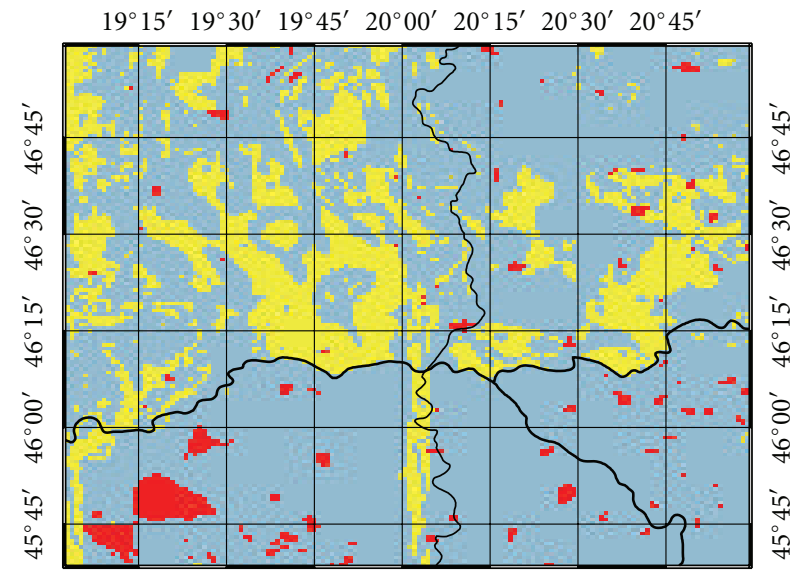

$19^{\circ} 15^{\prime} \quad 19^{\circ} 30^{\prime} \quad 19^{\circ} 45^{\prime} \quad 20^{\circ} 00^{\prime} \quad 20^{\circ} 15^{\prime} \quad 20^{\circ} 30^{\prime} \quad 20^{\circ} 45^{\prime}$

$\square$ Error

Not significant

Significant

FIgure 3: Spatial distribution of significant $(P<0.01)$ latent heat flux differences using soil hydraulic parameters determined from different soil databases.

Meteorological Archive and Retrieval System) database, with $0.125^{\circ}$ horizontal resolution and updated hourly.

\section{Case Studies}

From the measurement period, two days had been chosen for simulations. On 16 August 2011, a cold front passed the region a day before and a high pressure system was to be found to the west. High and mid-level clouds remained until late night. The minimum temperature was $16-19^{\circ} \mathrm{C}$, while the maximum was only $25-30^{\circ} \mathrm{C}$. On 26 August 2011, the synoptic conditions showed a high pressure system to the northeast and an approaching cold front from west which resulted strong southerly winds on lower levels. The day was cloud free, with $2 \mathrm{~m}$ temperatures between $17-22^{\circ} \mathrm{C}$ in the morning, reaching $32-37^{\circ} \mathrm{C}$ during afternoon.

\section{Results}

The difference between field capacity and wilting point is on average $30 \mathrm{~mm} / \mathrm{m}$ greater for HUNSODA derived soil parameters compared to MARTHA ones. Since the soil moisture initial condition is the same, on average it results in lower latent heat flux and higher surface temperatures, which should enhance PBL growth. The result of this effect is first looked closely on comparing measurements with the model simulations and then the spatial distribution of affected area is discussed.

8.1. Model Validation. The daytime course of PBL height estimations can be seen in Figure 2. The PBL height estimated from SNR shows a gradual building-up mixing layer during the day, while PBL height inferred from the radiometer changes quickly. In the latter case the inversion 

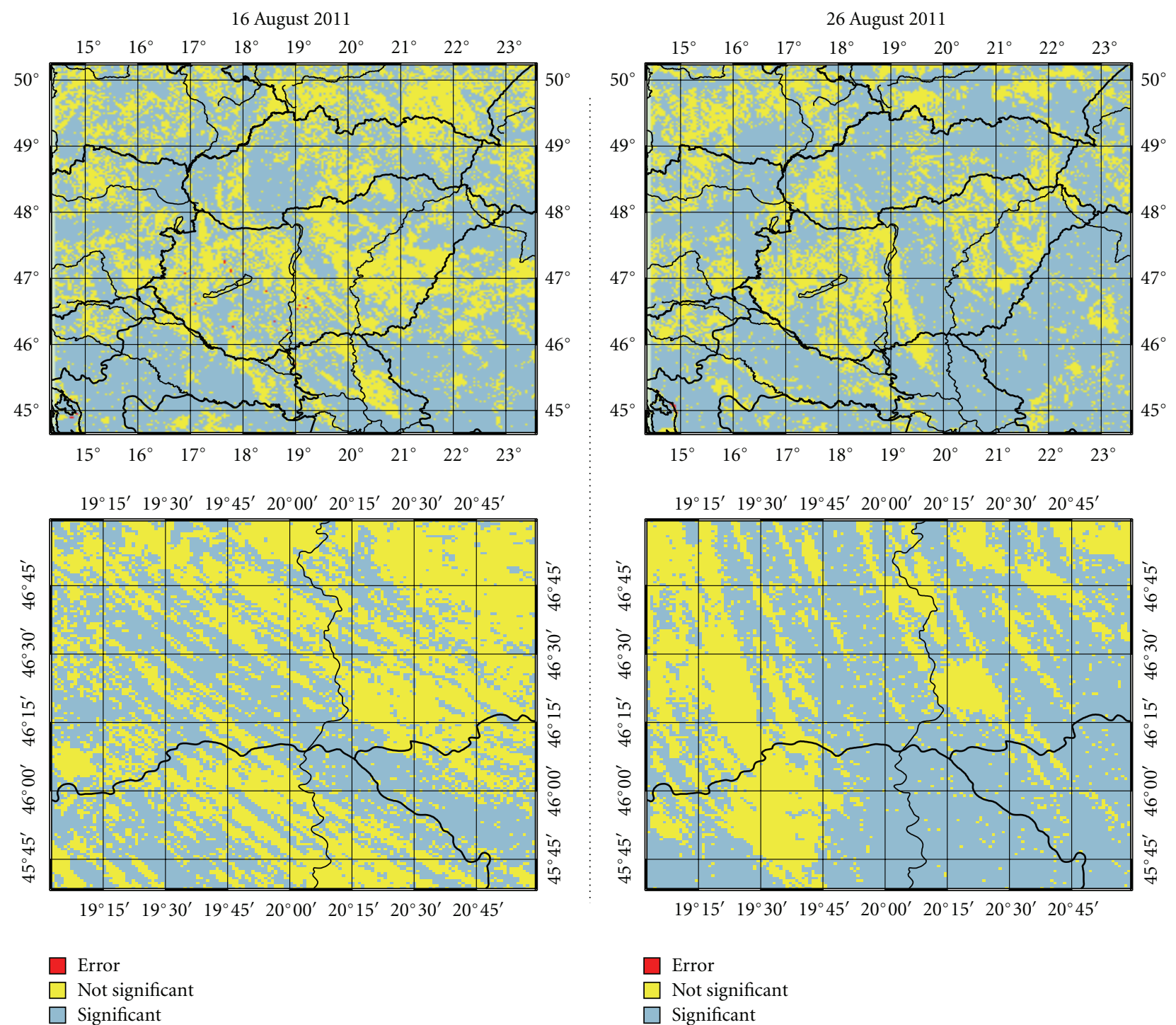

FIgURE 4: Spatial distribution of significant $(P<0.01)$ PBL height differences using soil hydraulic parameters determined from HUNSODA and MARTHA.

diminishes at around 4:00 UTC in both cases. Afterwards the potential temperature profile still shows the typical form of a stable atmosphere [29], but the heat from the incoming solar radiation enhances turbulent flow in the lower few hundred meters of the atmosphere, slowly making it unstable. This results in a decreasing estimated PBL height, as the potential temperature profile changes. After the mixing layer became unstable, the critical gradient in potential temperature was reached quickly. In the first case study the large scale stable environment slowed the change from stable to unstable stratification. At sunset the PBL height change was sudden, because the sign of potential temperature gradient in the lowest $100 \mathrm{~m}$ changed quickly. During night the windprofiler usually shows a higher PBL height, than the radiometric measurement. This mainly relates to the fact that the windprofiler only has 3 measurement levels in the lowest $750 \mathrm{~m}$, while the radiometer has 12 . The difference in the vertical resolution suggests that the windprofiler is not able to show the nighttime stable PBL layer correctly. However after reviewing a month of windprofiler measurements, it was found that during nighttime the maximum of SNR can reach up to $1000 \mathrm{~m}$ without any atmospheric trigger. This means however that during night the maximum of SNR indicates the top of the residual layer rather than the top of the stable PBL. PBL heights calculated by the model are the average of the 16 grid points in the nest which are nearest to the synoptic station. Simulations show good correlation with PBL height derived from both windprofiler and radiometer measurements. In the first case study, the maximum of the model simulated PBL height is closer to the one estimated with radiometer. The passing of the cold front resulted a synoptic scale downdraft which has a reducing effect on turbulent kinetic energy (TKE). Though the difference in soil parameters caused a difference in latent heat flux in average of about $25 \mathrm{~W} / \mathrm{m}^{2}$ and as a result a $0.5^{\circ} \mathrm{C}$ temperature difference occurred at $2 \mathrm{~m}$, the PBL height difference was 
small. It has to be noted that the northwestern wind was only between $1-3 \mathrm{~m} / \mathrm{s}$ through the whole day. On the second day, the effect of soil parameter difference is more obvious, since clouds were not present. Furthermore, as opposed to the previous case, strong $(6-7 \mathrm{~m} / \mathrm{s})$ southeastern flow characterized the lower $2 \mathrm{~km}$ atmosphere. The soil texture is clay loam southeast to Szeged (1) over a vast area in the model domain, for which the wilting point and field capacity soil moisture differs with $-41 \mathrm{~mm} / \mathrm{m}$ and $-86 \mathrm{~mm} / \mathrm{m}$, respectively. Over this type of soil texture the latent heat flux for HUNSODA parameters was reduced with about $40 \mathrm{~W} / \mathrm{m}^{2}$ compared to MARTHA simulations. As a result, at the measurement site the temperature was about $1^{\circ} \mathrm{C}$ higher during most of the day in case of HUNSODA. Along with the added heat from southeasterly flow, the TKE at $1000 \mathrm{~m}$ height was doubled compared to MARTHA simulations causing higher PBL height. The difference between model runs between 10 and 14 UTC is around $250 \mathrm{~m}$ ( 1 model level), and late afternoon is around $500 \mathrm{~m}$.

8.2. Significance Test. With the significance test, first the daytime (from 5 UTC to 17 UTC) course of latent heat flux has been analyzed (Figure 3.). On 16.08.2011, significant differences were found on the $54 \%$ of the mother domain. Usually over cites and lakes, no diurnal course was observed; in these cases the method cannot be applied, which is denoted as errors. The nest remarkably showed that in case of soil textures for which the parameters did not differ too much, the diurnal course did not change as well. For instance, the north-south directed patch of sandy loam along the Tisza River in Serbia is such a territory of nonsignificant differences. On the other day, 9\% more significant grid points occurred with respect to the former case. The territory of significant differences increased in Croatia and Slovenia and also on the Plain of Hungary. The sensible heat flux daytime course (not shown) was significant over $75 \%$ and $89 \%$ of the domain, respectively.

The spatial distribution of significant differences in PBL height (Figure 4) shows little correspondence to latent heat flux change. On the first day, 63\% of the grid point PBL heights showed notable difference, while this was $71 \%$ on the second day. The nest showed microstructure of the PBL height changes, parallel to the average wind direction. Daytime PBL height differences varied from 10-500 m, approximately $150 \mathrm{~m}$ on average.

\section{Conclusions}

Comparing high resolution nested WRF simulated PBL heights to measurements, the effect of soil parameters shows up in PBL height 5 hours after dawn. In some cases, the differences in PBL height can reach up to $500 \mathrm{~m}$. The sudden collapse of PBL around sunset corresponds to measurements obtained by both the windprofiler and radiometer. According to the significance test applied to diurnal courses of surface heat fluxes and PBL height, the spatial distribution of significant heat flux differences usually does not correspond to significant PBL changes prompted by soil parameter value differences. It has to be also noted that the latent flux daytime courses show less response to soil parameter differences than PBL height, primary due to sensible heat flux changes.

\section{Acknowledgments}

The project is supported by the European Union and cofinanced by the European Social Fund (Grant Agreement no. TÁMOP 4.2.1/B-09/1/KMR-2010-0003 and TÁMOP 4.2.2/B-10/1-2010-0030) and by the Hungarian Scientific Research Fund (OTKA K-81432). The authors also thank the help of István Aszalos with the radiometric data.

\section{References}

[1] M. C. McCumber and R. A. Pielke, "Simulation of the effects of surface fluxes of heat and moisture on a mesoscale numerical model. 1. Soil layer," Journal of Geophysical Research, vol. 86, no. 10, pp. 9929-9938, 1981.

[2] R. A. Pielke, "Influence of the spatial distribution of vegetation and soils on the prediction of cumulus convective rainfall," Reviews of Geophysics, vol. 39, no. 2, pp. 151-177, 2001.

[3] J. W. Deardorff, "Three-dimensional numerical study of the height and mean structure of a heated planetary boundary layer," Boundary-Layer Meteorology, vol. 7, no. 1, pp. 81-106, 1974.

[4] M. G. Schaap and F. J. Leij, "Database-related accuracy and uncertainty of pedotransfer functions," Soil Science, vol. 163, no. 10, pp. 765-779, 1998.

[5] Y. A. Pachepsky and W. J. Rawls, "Accuracy and reliability of pedotransfer functions as affected by grouping soils," Soil Science Society of America Journal, vol. 63, no. 6, pp. 17481757, 1999.

[6] M. Soet and J. N. M. Stricker, "Functional behaviour of pedotransfer functions in soil water flow simulation," Hydrological Processes, vol. 17, no. 8, pp. 1659-1670, 2003.

[7] R. Avissar and Y. Liu, "Three-dimensional numerical study of shallow convective clouds and precipitation induced by land surface forcing," Journal of Geophysical Research D: Atmospheres, vol. 101, no. 3, pp. 7499-7518, 1996.

[8] N. Mölders, "Plant- and soil-parameter-caused uncertainty of predicted surface fluxes," Monthly Weather Review, vol. 133, no. 12, pp. 3498-3516, 2005.

[9] J. A. Santanello, C. D. Peters-Lidard, S. V. Kumar, C. Alonge, and W. K. Tao, "A modeling and observational framework for diagnosing local land-atmosphere coupling on diurnal time scales," Journal of Hydrometeorology, vol. 10, no. 3, pp. 577599, 2009.

[10] G. Panegrossi, R. Ferretti, L. Pulvirenti, and N. Pierdicca, "Impact of ASAR soil moisture data on the MM5 precipitation forecast for the Tanaro flood event of April 2009," Natural Hazards and Earth System Science, vol. 11, no. 12, pp. 31353149, 2011.

[11] P. Seibert, F. Beyrich, S.-E. Gryning, S. Joffre, A. Rasmussen, and Ph. Tercier, "Mixing Height Determination for Dispersion Modelling. Report of Working Group 2," in COST Action 710-Final Report. Harmonisation in the Pre-Processing of Meteorological Data for Atmospheric Dispersion Models, EUR 18195 EN, 1998.

[12] D. J. Seidel, C. O. Ao, and K. Li, "Estimating climatological planetary boundary layer heights from radiosonde observations: comparison of methods and uncertainty analysis," 
Journal of Geophysical Research D, vol. 115, no. 16, Article ID D16113, 2010.

[13] W. M. Angevine, A. B. White, and S. K. Avery, "Boundarylayer depth and entrainment zone characterization with a boundary-layer profiler," Boundary-Layer Meteorology, vol. 68, no. 4, pp. 375-385, 1994.

[14] S. Liu and X. Z. Liang, "Observed diurnal cycle climatology of planetary boundary layer height," Journal of Climate, vol. 23, no. 21, pp. 5790-5809, 2010.

[15] H. Breuer, F. Ács, B. Laza, Á. Horváth, I. Matyasovszky, and K. Rajkai, "Sensitivity of MM5 simulated planetary boundary layer height to soil dataset: comparison of soil and atmospheric effects," Theoretical and Applied Climatology, In press.

[16] L. Pásztor, J. Szabó, and Z. Bakacsi, "Digital processing and upgrading of legacy data collected during the 1:25 000 scale Kreybig soil survey," Acta Geodaetica et Geophysica Hungarica, vol. 45, no. 1, pp. 127-136, 2010.

[17] J. Szabó, L. Pásztor, Zs. Bakacsi, B. Zágoni, and G. Csökli, "Kreybig Digital Soil Information System (Preliminaries, GIS establishment)," Agrokémia és Talajtan, vol. 49, pp. 265-276, 2000 (Hungarian).

[18] Z. Bakacsi, L. Kuti, L. Pásztor, J. Vatai, J. Szabó, and T. Müller, "Method for the compilation of a stratified and harmonized soil physical database using legacy and up-to-date data sources," Agrokemia es Talajtan, vol. 59, no. 1, pp. 39-46, 2010.

[19] L. Pásztor, Zs. Bakacsi, and J. Szabó, "Spatio-temporal integration of soil data originating from different sources for the estimation of national carbon stock in Hungary," Geophysical Research Abstracts, vol. 13, EGU2011-10960, 2011.

[20] A. Nemes, "Unsaturated soil hydraulic database of Hungary: HUNSODA," Agrokémia és Talajtan, vol. 51, no. 1-2, pp. 1726, 2002.

[21] Gy. Várallyay, "Influences of climate changes on soil moisture regime, texture and erosion," in Soils on a Warmer Earth, $\mathrm{H}$. W. Scharpenseel, M. Schomaker, and A. Ayoub, Eds., pp. 3949, Elsevier, Amsterdam, The Netherlands, 1980.

[22] A. Makó and B. Tóth, "MARTHA: the first detailed soil physical data base in Hungary," Agronapló 2008/3. 2008.

[23] G. S. Campbell, "A simple method for determining unsaturated conductivity from moisture retention data," Soil Science, vol. 117, pp. 311-314, 1974.

[24] W. C. Skamarock, J. B. Klemp, J. Dudhia et al., "A Description of the Advanced Research WRF Version 3. NCAR technical note," NCAR/TN-468+STR, 2008.

[25] E. J. Mlawer, S. J. Taubman, P. D. Brown, M. J. Iacono, and S. A. Clough, "Radiative transfer for inhomogeneous atmospheres: RRTM, a validated correlated-k model for the longwave," Journal of Geophysical Research D, vol. 102, no. 14, pp. 1666316682, 1997.

[26] P. Bougeault and P. Lacarrere, "Parameterization of orography-induced turbulence in a mesobeta-scale model," Monthly Weather Review, vol. 117, no. 8, pp. 1872-1890, 1989.

[27] G. Thompson, R. M. Rasmussen, and K. Manning, "Explicit forecasts of winter precipitation using an improved bulk microphysics scheme. Part I: description and sensitivity analysis," Monthly Weather Review, vol. 132, no. 2, pp. 519542, 2004.

[28] F. Chen and J. Dudhia, "Coupling and advanced land surfacehydrology model with the Penn State-NCAR MM5 modeling system. Part I: model implementation and sensitivity," Monthly Weather Review, vol. 129, no. 4, pp. 569-585, 2001.

[29] R. B. Stull, An Introduction to Boundary Layer Meteorology, Kluwer Academic Publishers, Dordrecht, The Netherlands, 1988. 

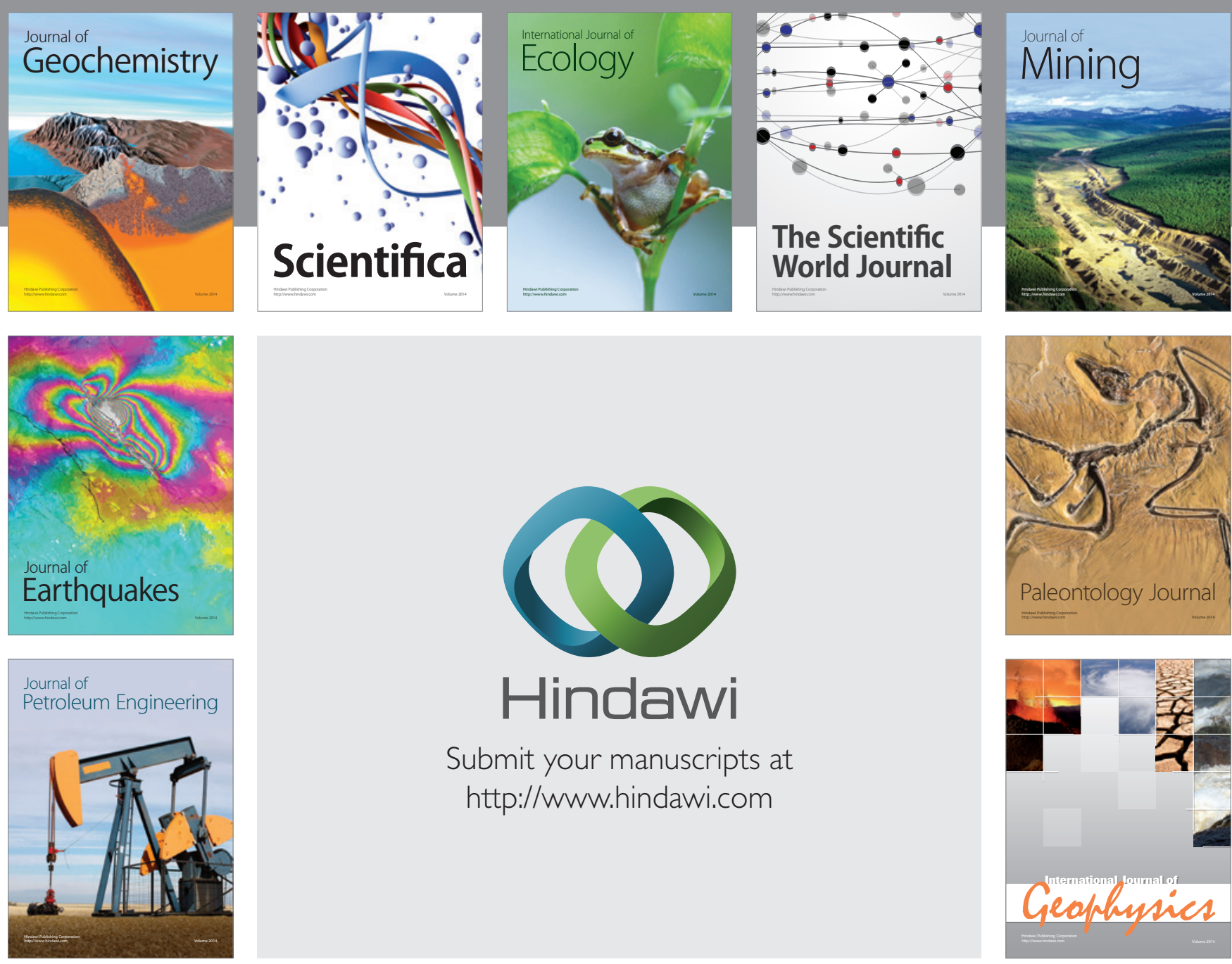

Submit your manuscripts at

http://www.hindawi.com
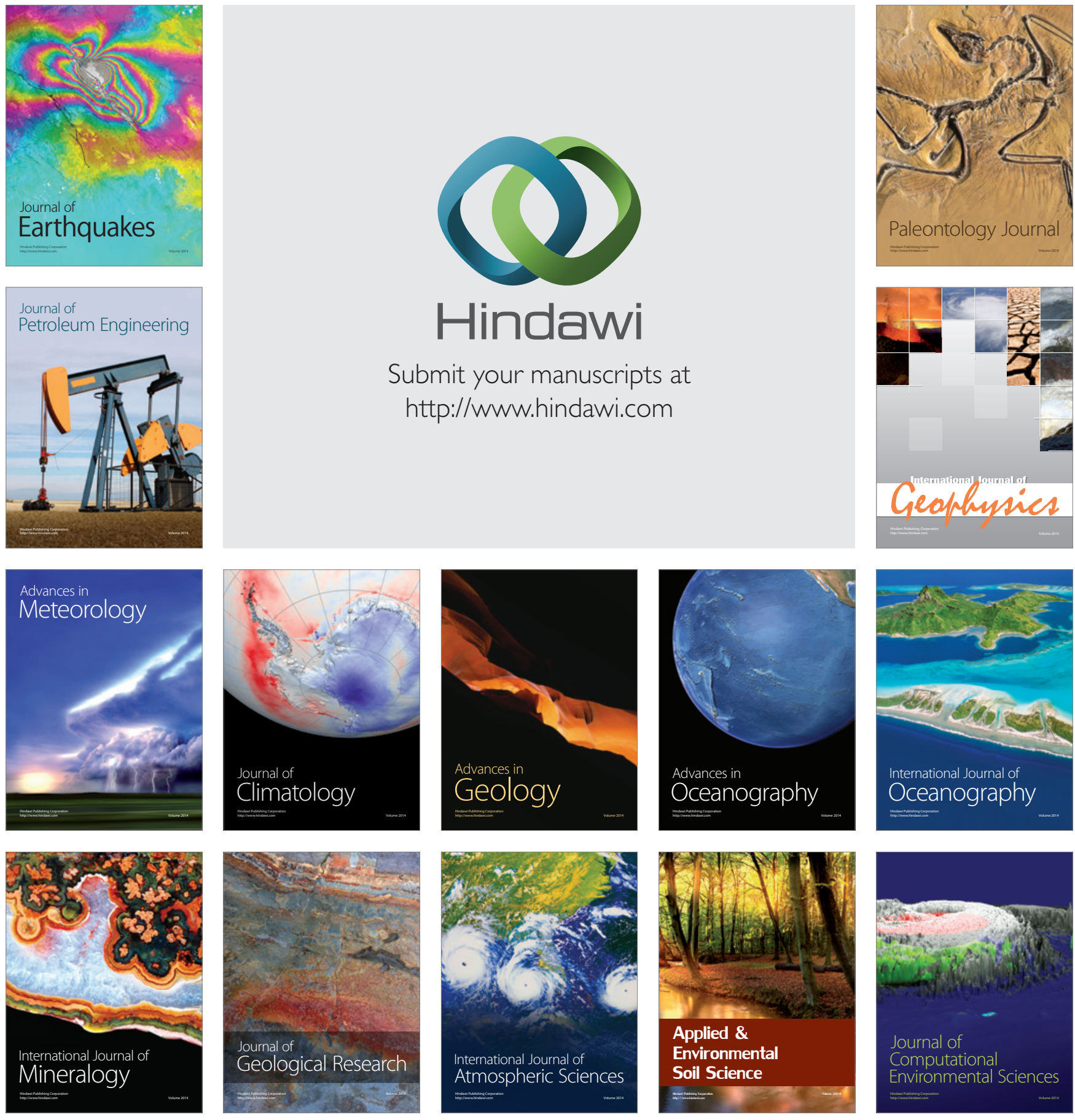